Ekonomia - Wroclaw Economic Review 27/3 (2021)

Acta Universitatis Wratislaviensis

No 4081

https://doi.org/10.19195/2658-1310.27.3.1

Nataliia Serohina

ORCID: 0000-0001-8612-6429

Odessa State Academy of Civil Engineering and Architecture

serohina.nata@gmail.com

Nataliia Petryshchenko

ORCID: 0000-0001-9172-9304

Odessa State Academy of Civil Engineering and Architecture

petrishchenkon@ogasa.org.ua

\title{
Features of labor activity during a pandemic and its impact on the economy in Ukraine
}

Date of submission: 30.06 .2021 ; date of acceptance: 9.08 .2021

JEL classification: J23, O15

Keywords: labor resources, digitalization, pandemic, profitability, social security

\section{Abstract}

Features of labor activity during a pandemic and its impact on the economy in Ukraine

The COVID-19 pandemic has significantly altered the way the global labor market works. Labor activity during the pandemic is increasingly moving into the field of digitalization and electronic lifestyles. This trend has led to significant changes in the quality of the population's life, as well as in the economic activities of manufacturers and sellers. This demonstrates the need for a more detailed study of trends in the development of the labor market and potential changes in the employment of labor resources.

Some of the main structural components affecting the state of the country's economy in a pandemic are highlighted. For the analysis, this includes the level of employment and the change in the profile of labor resources, as well as the income and losses of the country's enterprises, and the GDP dynamics.

This choice is due to the fact that labor resources are the productive force of the enterprise, which affects the efficiency of activities and profitability. In the existing conditions, the search for opportunities to improve the current order of labor organization is becoming relevant. 
The purpose of the article is to determine the main trends in the development of the Ukrainian economy, taking into account the negative impact of the pandemic, to identify the dynamics in the composition of the country's labor resources, and to propose possible ways to reduce the negative consequences of lockdowns and production interruptions. The factor of profitability of the production spheres, which determines the socio-economic development of the state, is also considered. Depending on this factor, disproportions are formed at the levels of socio-economic development.

Based on the data of state statistics and using the methods of empirical and mathematical research, the analysis of the dynamics of the main indicators has been carried out. Based on the data obtained on the sphere of work and financial performance of enterprises for 2020, an economic diagnostics of their unprofitableness was carried out. The method of horizontal and vertical analysis revealed a decrease in the employed population of the country, an increase in the unemployment rate, and a decrease in GDP. Calculations of the dynamics and structure of incomes and losses of Ukrainian enterprises made it possible to identify the most unprofitable sectors of the economy.

In most cases, a change in the organization of work leads to the adaptation of the activities of the enterprise, taking into account certain conditions. The transfer of part of the workforce to work using remote methods allows not to stop production and support the country's economy with the introduction of quarantine (lockdown). This serves as an adequate alternative compared to the prospect of dismissal of workers, which will affect not only the financial security of the population, but also the profitability of production spheres.

In a pandemic, filling the budget is extremely important. This will allow funding to support entrepreneurship, vaccinations and social security for most of the population. Digitalization and remote work are a promising area that will take a significant place in the organization of work in the future.

The main task of the state should be to create algorithms and standards for the social protection of people, as well as state support of enterprises.

\section{Introduction}

The COVID-19 pandemic and the introduction of mandatory and advisory quarantine measures significantly affected the plans of employers. In some companies, for the period of restrictions, it was decided to send employees on vacation for an indefinite period, and some companies cut salaries. Most employers expected the situation to develop, which is why the recruitment of employees was suspended. Some companies representing certain areas of activity, on the other hand, began to hire personnel. Such changes have significantly influenced the state of the labor market. It was also reflected in the volume of companies' activities and their profitability.

The situation that has arisen has shown the need to reorient the activities of many companies to other types of work and services. But not all companies were able to follow such changes without worsening their economic and financial performance. The need for possible solutions to this problem has actualized research in this direction. 


\section{Theoretical framework of the research}

Society's labor resources have been accumulating over generations. Their composition is influenced by the demographic situation, standard of living, education, social security and many other factors.

Changes in the nature of transformations and trends in the development of the world of work lead to multi-vector and contradictory changes in all components of social and labor development under the influence of:

a) factors of a demographic, technological, globalization, institutional nature, the action of which over the past years has led to the formation of a new social and labor platform "Labor 4.0";

b) factors of an epidemiological, quarantine and restrictive nature, which, after the announcement of the COVID-19 pandemic, radically changed economic, social life and the world of work (Kolot, 2020).

Progress in reducing global unemployment has not been matched by adequate improvements in the quality of jobs, according to the report of the International Labor Organization (2019), "Prospects for employment and social protection in the world in 2019". The report also notes that some modern business models, including those based on new technologies, threaten to undermine existing achievements in the field of labor.

The invariability of the existing situation can lead to such negative consequences as: strengthening the informal nature of employment, instability in the labor market, weakening social protection, non-observance of labor standards. Inequality and problems in the world of work have been observed even before the introduction of lockdowns in many countries around the world. The COVID-19 pandemic has not changed the global employment situation for the better.

Low wages, informal work and work inadequate for the worker's qualifications are the reasons that ensure the low level of financial well-being of the established part and lead to their social insecurity. With the introduction of isolation in different forms, the consumption of goods and products of the population decreased. The pandemic has exacerbated the attendant problems with labor.

Since the beginning of 2020, the health crisis associated with the COVID pandemic has severely reduced economic activity in the European Union. Many people were unemployed, and some were no longer able to continue looking for new jobs. Many companies have made reductions in the number of their employees or reduced their working hours. The number of unemployed grew steadily (Eurostat Statistics Explained, 2021).

COVID-19 is an example of a global health crisis in today's world. This crisis affects almost all sectors of the economy, both locally and globally (Chi-Wei et al., 2021). 
The Ukrainian labor market has been influenced by the negative impact of the COVID-19 pandemic in several directions at once. Firstly, the development of the situation in the Ukrainian labor market is influenced by changes in that segment of the national economy, the functioning of which is focused on the domestic market of Ukraine. Secondly, negative changes have appeared in the segment of the national economy, the functioning of which is oriented towards the external (world) market. Thirdly, the development of the situation in the Ukrainian labor market is influenced by changes in the situation regarding the direct migration of labor from Ukraine abroad (Kulitsky, 2020).

Labor restrictions introduced in the context of the COVID-19 pandemic have significantly affected the state of the Ukrainian economy. The consequences of such restrictions will have a long-term impact.

Among the economic consequences of the pandemic, the crisis changes in the labor market have significant effects. In connection with the partial or complete suspension of the work of enterprises, the following effects are observed: an increase in unemployment in various forms, a slowdown in the growth of real wages and a decrease in the general welfare of workers, which negatively affects the consumer sentiment of workers and consumer demand (Tyshchenko, 2020).

\section{Research methodology}

The work uses the methods of empirical research: observation, comparison, measurement. Based on the data obtained from state statistics on the main indicator of work and financial performance indicators of enterprises for 2020, diagnostics were carried out, general trends were identified, and possible development forecasts were noted. The method of horizontal and vertical analysis revealed a decrease in the employed population of the country, an increase in the number of unemployed, and a decrease in GDP. Calculations of the dynamics and structure of incomes and losses of Ukrainian enterprises made it possible to identify the most unprofitable sectors of the economy.

\section{Analysis of the research results or scientific problem}

The crisis that has arisen due to the COVID-19 pandemic has shown at what a high level the relationship between the country's economy and the labor market is. Table 1 shows statistical data that demonstrate the dynamics of the number of labor resources and their productivity, in relation to unemployment and the consumer price index. 
Table 1. Indicators of the relationship between total employment and labor productivity with the COVID pandemic

\begin{tabular}{|c|r|r|r|}
\hline Indicator & \multicolumn{1}{|c|}{2018} & \multicolumn{1}{c|}{2019} & \multicolumn{1}{c|}{2020} \\
\hline $\begin{array}{c}\text { Number of employed population } \\
\text { aged 15-70, total }\end{array}$ & 16360.90 & 16578.30 & 15915.00 \\
\hline $\begin{array}{c}\text { Unemployed population aged } \\
\text { 15-70 years, total, thousands person }\end{array}$ & 1578.60 & 1487.70 & 1674.00 \\
\hline Unemployment rate, \% & 9.65 & 8.97 & 11.00 \\
\hline Gross domestic product & 3560302.00 & 3977198.00 & 4191864.00 \\
\hline Consumer price indices & 110.90 & 107.90 & 105.00 \\
\hline GDP growth rate & - & 111.71 & 105.40 \\
\hline $\begin{array}{c}\text { GDP per person employed } \\
\text { at the age of 15-70 }\end{array}$ & 217.61 & 239.90 & 263.39 \\
\hline
\end{tabular}

Source: compiled by the authors based on data from State Statistics Service of Ukraine (2021).

From the data in the table, we can conclude that in 2020 , the number of the employed in the population has significantly decreased by 663.3 thousand people. The number of people looking for work has increased by 186.3 thousand. Taking into account the methodology for calculating the number of unemployed which is used in Ukraine, we can talk about an increase in the informalization of the labor of the unemployed. People find informal work, part-time jobs, do not register at the labor exchange, in employment centers. This trend should be called negative for the state, since the lack of interest in official services for social support and employment indicates a decrease in the population's respect for public services.

Comparing the GDP growth rate and the consumer price index, it should be noted that in 2019, there was an increase in GDP of $3.81 \%$, but in 2020 , the growth was only $0.4 \%$. The increase in GDP only occurred due to the rise in prices.

The COVID-19 pandemic has brought significant changes to the world of work. Thesechanges haveaffected workplaces, the financial well-being of the workforce, and entrepreneurship.

Unemployment is a problem for every country, including Ukraine. Figure 1 shows the growth of unemployed in 2020 by age group.

So, in 2020, there was an increase; a group of labor resources aged 15 to 24 was especially actively looking for work during 2020. This sharply revealed the problem of youth employment and the undesirable behavior of employers in the difficult period of recruiting people with inexperience.

When the isolation regime is introduced, the processes of supply of foreign direct investment are disrupted and supply chains are destroyed. This has negative consequences for businesses, including jobs. In some areas of the national economy, it was possible to switch to online work with a fairly high degree of success. 


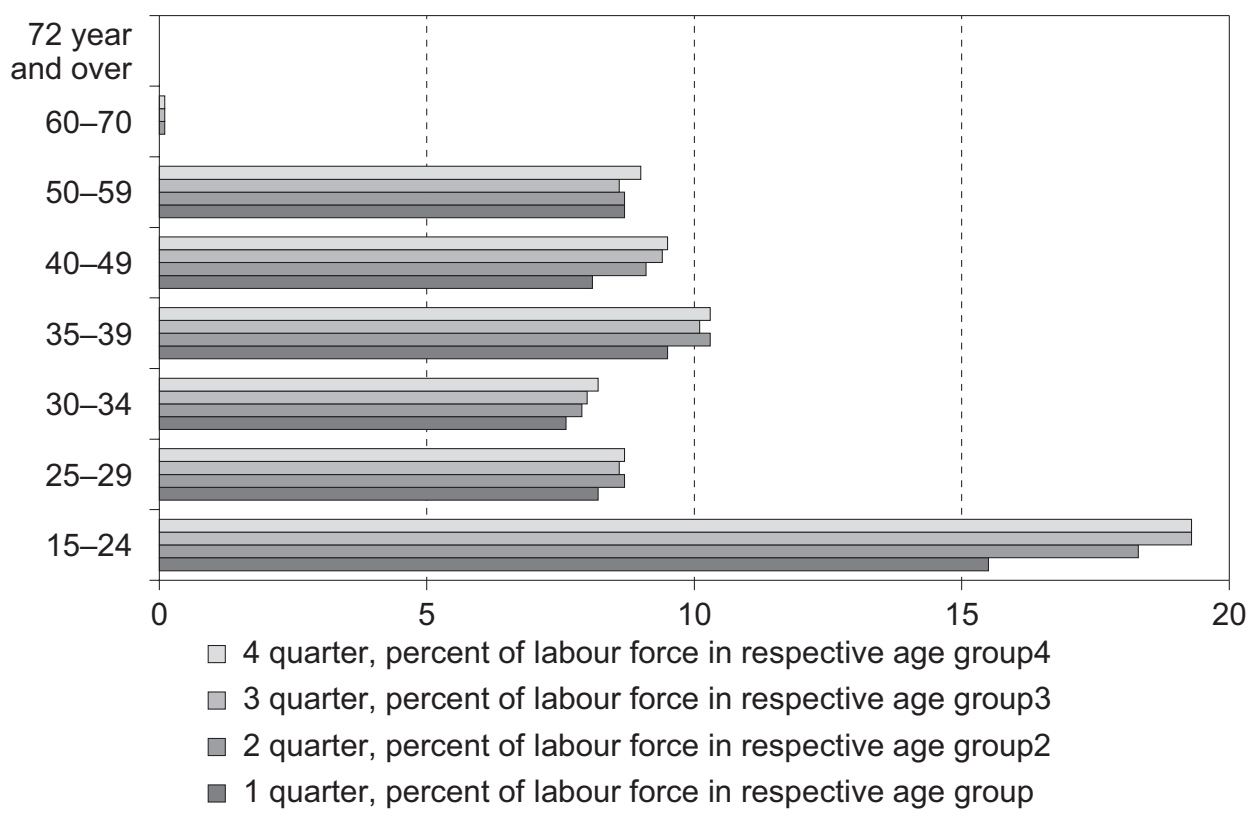

Figure 1. Dynamics of the number of unemployed in 2020 (by age groups)

Source: compiled by the authors based on State Statistics Service of Ukraine (2021).

In the regions of application, the introduction of quarantine led to a halt in production as a result of the job reduction and the inability to restore them in full due to losses during the interruption of production activities. This is especially true for those industries that were in unfavorable conditions even before the introduction of quarantine; some of them are simply closed. This also applies to small and medium-sized businesses, which are are important players in the development of the economy. But in conditions of reduction and restriction of activities, they incur significant losses, which can lead to bankruptcy.

In 2019, 1941701 business entities were registered in Ukraine, of which 1561028 (80.39\%) are entrepreneurs, and 380673 (19.61\%) are enterprises. For 2020 , the information of state statistics has not yet been updated, but a clear decrease in GDP and an increase in the unemployed indicate a decrease in the number of economic entities in all sectors.

An analysis of the number of unprofitable enterprises in Ukraine over the past two years has shown that in some industries the growth of unprofitable enterprises has significantly higher rates than in others. The growth dynamics of unprofitable enterprises in individual industries is shown in Figure 2. 


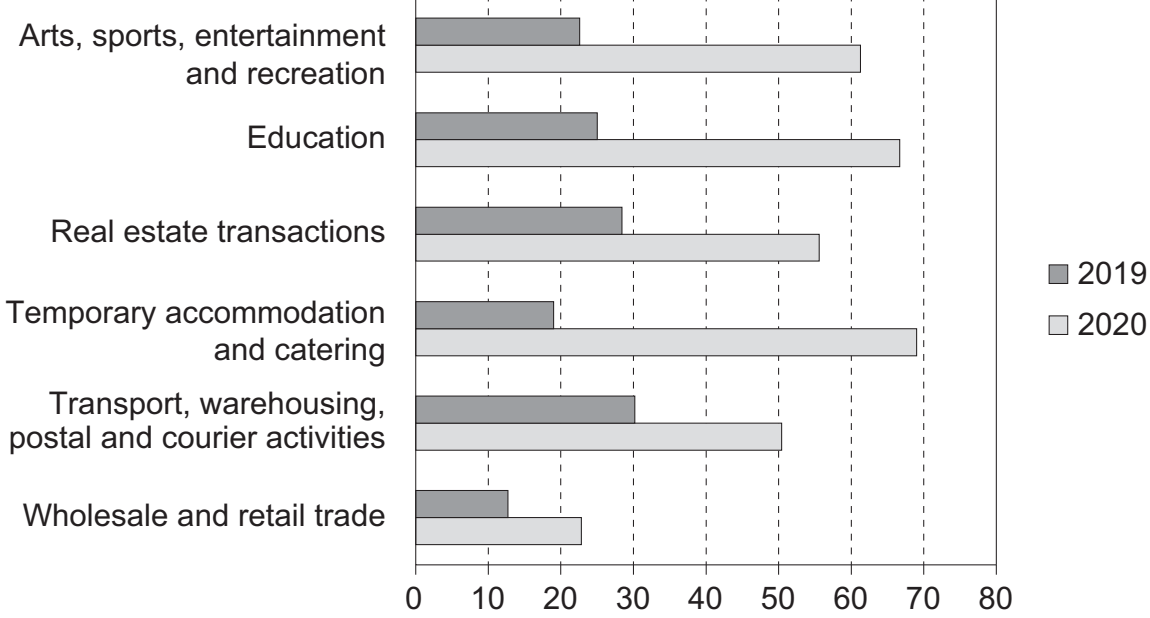

Figure 2. The share of unprofitable enterprises in the total number of enterprises in the industry, $\%$

Source: complied by the authors on the basis of State Statistics Service of Ukraine (2021).

Analyzing the diagram, we can say that the largest increase in unprofitable enterprises was noted in the following areas:

- temporary accommodation and catering - by $72.5 \%$;

— arts, sports, entertainment and recreation — by $63 \%$;

— education - by $62.5 \%$;

— real estate transactions - 49\%;

— wholesale and retail trade - 44\%;

— transport, warehousing, postal and courier activities - 40\%.

According to the nature of their activities, the abovementioned were the most affected by the changes in connection with the introduction of quarantine restrictions. Some of the limits were positive and some were negative.

In the field of personnel management, due to such conditions, new issues arise and expand, related to the volume of hiring, remuneration, the transition to remote work, the distribution of work tasks and control over their implementation, compliance with anti-epidemic rules in the process of work, and the preservation of employee loyalty to the organization (Pristupa, 2020).

For a more detailed understanding of the situation, it is necessary to consider the development trends of enterprises that relate to the above industries. The dynamics of changes in financial results is shown in Table 2.

The data in Table 2 show that the profitability of enterprises across all sectors considered decreased in 2020. This most significantly affected the wholesale and retail trade, as well as transactions with real estate. Trade enterprises urgently needed to reorient their activities to online trade, but not all enterprises in Ukraine had such an opportunity. One of the reasons for the emergence of problems with 
the transition to online trading was the uncertainty of the timing of the quarantine introduction, which disorientated sellers when determining priorities in the ways of selling goods. The most vulnerable were sellers in large commercial industrial markets, the mechanism of activity of which was geographically linked not only to a retail outlet, but also to warehouses. Accordingly, when the markets were closed, the physical possibilities of serving customers were limited, including during online trading.

Table 2. Dynamics of the results of the activities of enterprises

\begin{tabular}{|c|c|c|c|c|c|c|c|}
\hline & \multirow{2}{*}{$\begin{array}{c}2019 \\
\begin{array}{c}\text { Financial } \\
\text { results }\end{array}\end{array}$} & \multicolumn{3}{|c|}{2020} & \multicolumn{2}{|c|}{ Deviation } \\
\hline & & & Profit & Lesion & $\begin{array}{c}\text { Financial } \\
\text { results }\end{array}$ & absolute & relative \\
\hline 1 & $\begin{array}{l}\text { Wholesale and } \\
\text { distribution of } \\
\text { trade }\end{array}$ & 129113.3 & 76607.9 & 46994.5 & 29613.4 & -99499.9 & -77.06 \\
\hline 2 & $\begin{array}{l}\text { Transport, } \\
\text { warehousing, } \\
\text { shipping and } \\
\text { handling }\end{array}$ & 14414.8 & 54141.6 & 40718.8 & 13422.8 & -992.0 & -6.88 \\
\hline 3 & $\begin{array}{l}\text { Temporary } \\
\text { accommo- } \\
\text { dation and } \\
\text { catering }\end{array}$ & 4648.0 & 935.3 & 4131.3 & -3196.0 & -7844.0 & -168.76 \\
\hline 4 & $\begin{array}{l}\text { Real estate } \\
\text { transactions }\end{array}$ & 47317.5 & 6568.3 & 14273.1 & -7704.8 & -55022.3 & -116.28 \\
\hline 5 & Education & 377.7 & 6.5 & 92.9 & -86.4 & -464.1 & -122.88 \\
\hline 6 & $\begin{array}{l}\text { Arts, sports, } \\
\text { entertainment } \\
\text { and recreation }\end{array}$ & 120.3 & 629.0 & 1634.8 & -1005.8 & -1126.1 & -936.08 \\
\hline
\end{tabular}

Source: compiled by the authors based on State Statistics Service of Ukraine (2021).

Significant losses in the field of real estate operations are explained by the reduction in the financial well-being of the population, the reduction of jobs or the length of time, the rise in prices for goods and services, and significant costs of medicine. In the absence of financial stability, people tend to accumulate funds and refuse large purchases. In these industries, the amount of decline in financial results is quite large: UAH 99499.9 thousand in the field of trade and UAH 55022.3 thousand on real estate transactions. But the rate of decline in profitability is not so great: $77 \%$ and $116 \%$.

Considering the results of Table 2 precisely from the standpoint of the rate of decline in financial results, it is also possible to highlight 2 industries. In the sphere of art, sports, entertainment and recreation, the financial result decreased by $936 \%$, and in the sphere of temporary accommodation and catering by $168.76 \%$. 
Despite the fact that the monetary value of this decline is not as significant as in the aforementioned industries, it can be considered critical. Enterprises in industries did not have alternative services under conditions of mandatory or advisory quarantine restrictions. It was in this activity that the greatest problems with retention of the local labor force were found. Accordingly, the number of jobs in this area has significantly decreased.

The smallest level of decline in financial results and an insignificant amount financial losses can be observed in the field of transport, warehousing, postal and courier activities. This area is distinguished by its multicomponent nature, which makes it possible to compensate for the growth of losses in the transport component of the growth of profitability in postal and courier activities. It should also be noted that there is an increase in jobs in postal and courier businesses. But this trend does not correspond to the number of job losses, which is confirmed by the growth of unemployment in Ukraine.

Currently, there is an active development of modern technologies and the need for a transition to a new level of work. The need for this is now very urgent. The introduction of quarantine (lockdown) served as a catalyst for this process. The transition to remote work, increased digitalization contributed to changes in the quality of the population's life.

In many Ukrainian companies, institutions and organizations that are guided by modern management approaches in work, distance employment as a form of labor organization has already been tested in practice to one degree or another, since it has a number of advantages over traditional work. The main ones are:

- expanding the geography of attracting labor force, which allows the employer to hire employees with unique competencies in any region of the country and beyond;

- the possibility of implementing a project-based approach to recruiting labor, according to which specialists do not sign up on a permanent basis, but for the performance of work within the framework of the implementation of specific projects;

- this approach allows employers to regulate the degree of employment of each of the employees within the limits of necessity;

- no downtime in work caused by the inability for the employee to be physically present at the workplace (Kolomiets, 2020).

This process can be seen as a positive change, but there are also negative aspects associated with the fact that such forms of work cannot be introduced in all industries. This contributes to the development of risky situations. As a consequence, this can lead to an increase in unemployment and the destabilization of the economic situation in the country.

Digital transformation is the introduction of modern technologies into the business processes of an enterprise. This approach implies not only the installation of modern equipment or software, but also fundamental changes in approaches to management, corporate culture, and external com- 
munications. As a result, the productivity of each employee and the level of customer satisfaction are increased, and the company gains a reputation for being a progressive and modern organization. (Terrasoft, 2020)

The digitalization of processes in production and the economy in modern times is very relevant. Whole industries choose this path of development for themselves as the only opportunity to meet the rapidly changing conditions of the surrounding world. The pandemic has increased the need for digitalization at times. There is a dynamic transformation of industry, retail trade and the public sector.

Thanks to the pandemic, digital technologies are beginning to receive additional arguments in favor of their development, and it's time to ask the question: what turned out to be more important here - digitalization, which needs a catalyst, or a pandemic that accidentally turned out to be a catalyst for the development of digital technologies? (Conference, 2020)

Comparing the advantages and disadvantages of digitalization, the main ones should be noted:

- publicity and visibility, access to information from anywhere in the world makes remote work convenient, but deprives of an element of live communication. In addition, the information may be unreliable;

- convenient receipt of information (mail, smartphone screen, etc.) will limit the motor and speech skills of the "digital generation," which will entail an intellectual collapse (Lapteva, 2020);

- algorithmization of activities, ready-made forms, templates, answers will significantly speed up the production of goods and services, but will entail a decrease in creativity, deformation of a person's personality, quotation thinking.

\section{Conclusions}

The COVID-19 pandemic has caused many negative long-term changes in the global economy, especially in the labor market. The Ukrainian labor market is no exception. The analysis revealed a significant reduction in GDP growth, an increase in the number of unemployed and an increase in unprofitable enterprises. The most severely affected by the lockdown are such industries as transport and passenger transportation, trade, production and sale of industrial goods, tourism, public catering, and entertainment enterprises. Such changes cause social tension, which negatively affects the political and economic stability of the country.

The study indicated the need to develop a set of measures to prevent the negative impact on the labor market associated with the digitalization of production. It is also necessary to realize the possibility of a situation arising in the future. However, the issues of state support of enterprises in the context of a lockdown and preservation of jobs remain open for discussion. The problem of taxation is also important, since the direction of online business control is poorly developed in Ukraine. 
It is necessary to eliminate the "weaknesses" in the world of work that were identified during the introduction of the lockdown: strive to create flexible systems for organizing work with the introduction of mandatory or recommendatory restrictions that allow them to incur minimal financial losses.

Development of programs for responding to external influences on the transition of workers to remote work for the sale of goods and reorientation through orders on the Internet. Increasing the level of social and financial protection of the company's employees. These changes are possible by providing support to enterprises, which will save jobs and ensure profitability. Accordingly, investment in social protection programs is needed. At the same time, such problems should work to stabilize the economic situation in the country.

All of these areas require interaction between government and workers' and employers' organizations to find effective, practical and fair solutions to the problems facing the world of work. In Ukraine, such ways of organizing work are underdeveloped, which leads to negative consequences during the COVID-19 pandemic.

\section{References}

Chi-Wei, S., Dai, K., Ullah, S., Andlib, Z. (2021). COVID-19 pandemic and unemployment dynamics in European economies. Economic Research-Ekonomska Istraživanja. DOI: 10.1080/133 1677X.2021.1912627.

The Russian Federal Bar Association. (2020). Плюсы и минусы иифровизации [Pros and Cons of Digitalization]. Date of access: 19.02.2021, https://fparf.ru/news/fpa/plyusy-i-minusy-tsifrovizatsii/.

Kolomiets, O.O. (2020). Поширення дистанційної зайнятості як фактор підвищення економічної стійкості [Expansion of distance employment as a factor of enhancing the economic sustainability]. Ekonomichnyj visnyk NTUU «KPI». DOI: 10.20535/2307-5651.17.2020.216321.

Kolot, A., Gerasimenko, О. (2020). Сфера прачі в умовах глобальної сочіоекономічної реальності 2020: виклики для україни [Field of work in the condition of global socio-economic reality 2020: Challenges for Ukraine]. Date of access: 29.05.2021, https://library.fes.de/ pdf-files/bueros/ukraine/16344.pdf.

Kulitsky, S. (2020). Український ринок праці під впливом пандемії COVID-19: стан та оцінка перспектив розвитку [Ukrainian labor market under the influence of the COVID-19 pandemic: status and assessment of development prospects]. Date of access: 18.06.2021, http:// nbuviap.gov.ua/index.php?option $=$ com_content\&view $=$ article $\& i d=4941$ : situatsiya-na-vitc hiznyanomu-rinku-pratsi-v-umovakh-pandemiji\&catid $=8 \&$ Itemid $=350$.

Lapteva, I.W., Pakhmutova. E.D. (2020). Advantages and disadvantages of digitalization of liberal education. Вестник Самарского университета. История, педагогика, филология [Vestnik of Samara University. History, pedagogics, philology], 26 (1). DOI: 10.18287/2542-04452020-26-1-89-94.

Pristupa, M.V.(2020). Зміни практик управління персоналом в умовах пандемії (за результатами наративних експертних інтерв'ю) [Changes in human resources management in a pandemic (for the results of narrative expert interviews)]. SOCIOPROSTIR: mizhdystsyplinarnyj elektronnyj zbirnyk naukovykh prats'z sotsiolohii ta sotsial'noi roboty), 10. DOI: 10.26565/22182470-2020-10-03.

Ekonomia - Wroclaw Economic Review 27/3, 2021

(C) for this edition by CNS 
Eurostat Statistics Explained. (2021). Labour market slack - unmet need for employment - quarterly statistics. Date of access: 22.06.2021, https://ec.europa.eu/eurostat/statistics-explained/ index.php?title=Labour_market_slack___unmet_need_for_employment_-_quarterly_statistics.

International Labour Organization. (2019). Report. World Employment and Social Outlook: Trends. Date of access: 15.01.2021, https:/www.ilo.org/global/research/global-reports/weso/2019/ WCMS_670542/lang--en/index.htm.

State Statistics Service of Ukraine. (2021). Statistical data. Date of access: 2.04.2021, http://www. ukrstat.gov.ua/.

Terrasoft. (2020). Что такое цифровая трансформация компании? [What is digital transformation of a company?]. Date of access: 12.12.2020, https://www.terrasoft.ru/page/digital-transformation.

Tyshchenko, V.V. (2020). Вплив пандемії COVID-19 на економічну активність в країнах світу [The influence of the COVID-19 pandemic on the economic activity worldwide]. Mizhdystsyplinarni naukovi doslidzhennia: osoblyvosti ta tendentsii: materialy mizhnarodnoi naukovoi konferentsii, vol. 1. 24-26. Chernihiv: MCND. 